\title{
Organizational Performance and Sustainability in Manufacturing and Service through TQM Implementation
}

\author{
Hesham Magd1, Henry Karyamsetty² \\ ${ }^{1}$ Quality Assurance and Accreditation, Faculty of Business and Economics, Modern College of Business and Science, Muscat, \\ Oman \\ ${ }^{2}$ Transportation, Logistics and Safety Management, Modern College of Business and Science, Muscat, Oman \\ Email: Hesham.Magd@mcbs.edu.om, Henry.Karyamsetty@mcbs.edu.om
}

How to cite this paper: Magd, H., \& Karyamsetty, H. (2020). Organizational Performance and Sustainability in Manufacturing and Service through TQM Implementation. Open Journal of Business and Management, 8, 2775-2804.

https://doi.org/10.4236/ojbm.2020.86172

Received: October 28, 2020

Accepted: November 24, 2020

Published: November 27, 2020

Copyright $\odot 2020$ by author(s) and Scientific Research Publishing Inc. This work is licensed under the Creative Commons Attribution International License (CC BY 4.0).

http://creativecommons.org/licenses/by/4.0/

\begin{abstract}
Total Quality Management (TQM) has emerged in today's business environment as a strategy for achieving competitive advantage, organizational performance, sustainability and excellence. TQM has originated from manufacturing sector and it believed to be applicable to all sectors, due to its logical conception of achieving organizational long-term goals through a systematic approach. From the growing expansion of manufacturing and service sector industries, TQM concept globally has become an important pillar for growth and development. Manufacturing and service organizations have similarities and differ in the way operations are carried out by them (Jiang, 2009), but both believe in the value of successful implementation of TQM. Successful implementation of TQM is claimed to be contingent on TQM practices and these practices may differ in manufacturing and service organizations. However, the authors believe that organizational excellence can be achieved if there is better management of TQM practices in manufacturing and service organizations. Identifying the key contributing TQM practices/factors remains a challenge, and therefore the purpose of the study was to examine current TQM Practices/factors that impact on organizational performance, excellence and develop a TQM Implementation model pathway for manufacturing and service organizations to adapt in helping achieving the desired outcome of TQM.
\end{abstract}

\section{Keywords}

TQM, Manufacturing, Service, TQM Practices/Factors, Sustainability, Excellence 


\section{Introduction}

In today's business environment, quality plays an important role in business success since it determines the superiority of a product, goods or service rendered by the industry to the consumers and customers. In order to thrive over competitors in the industrial sector, industries have to emphasize on maintaining quality in all stages of business operations and eventually this leads all business establishments to follow the concept of quality management system (QMS) which involves policies, processes and procedures for improving quality at every stage of operation. To maintain the competitiveness and assurance of product/service quality, different strategies were integrated to realize the importance of conceptualizing the total quality management system (TQM) in organizations (Magd \& Curry, 2003).

Total quality management (TQM) is a management approach to organizational performance facilitating continual improvement by identifying and eliminating errors happening in production process and taking steps appropriately for streamlining the supply chain network and enhancing customer satisfaction. The concept of quality management is known to have originated in 1920s as management principles which evolved gradually over years by integrating quality control, quality assurance and quality improvement into structured and systematic approach leading to development of total quality management system (TQM) (Metaxas \& Koulouriotis, 2014).

TQM principally aims to improve the quality of the products, goods and services and improving the organizational performance, and in turn leads to organizational excellence. The management system though known to have originated from manufacturing sector is widely applicable to all industries due to its logical conception of achieving organizational long-term goals through systematic change. Developing globalization and steady growth in industrial establishment over the past two decades has not only emphasized the TQM application to all industrial sectors but also proven to lay successful foundation for achieving organizational goals.

Currently, TQM has become a comprehensive approach in organizations that has wider scope of application considering all areas of the business operations to improve productivity, ensure business continuity and enhance customer satisfaction. Its success can be gauged from the commitment of senior management showing effective leadership at all levels of the organization (Dale \& Cooper, 1994). Therefore, TQM in business is competitive factor to be established and implementation is imperative to every organization management to maintain sustainability and enhance performance of products, goods or services.

Considering this concept as reference, this paper attempts to provide an understanding of TQM as an approach and identify the various practices that would possibly influence and sustain organization performance especially in manufacturing and service sectors.

The research study includes introduction which highlights the background of 
TQM and its importance to the current business market scenario, followed by the thorough review of literature on the TQM concept, understanding and critically analyses on the significance of various TQM practices that influence organizational performance in both manufacturing and service sectors. Thereafter the barriers involved in TQM implementation in both the sectors specifically are identified and outlined together with the literature review. As an outcome of the study conceptual framework and working model for organisations to implement in order to improve their performance and achieve sustainability is developed and proposed. Finally, in the end the critical outcomes of the study are summarized which is presented in the conclusion.

\section{Literature Review}

\subsection{TQM: An Understanding}

Over the years, business organizations have witnessed the evolution of quality through different stages ranging from inspection, quality control, quality assurance to total quality management (Figure 1). Inspection focuses on the examination, measurement, testing, and assessment of one or more characteristics of a product, service or activity and compared with certain standards to assess its conformity. Quality control focuses on the quality of the products, quality assurance tends to focus on products and process and total quality management focuses on the whole organization as one unit (Dale, 2003; Shouman \& Othman, 2014). (Dale, Wiele, \& Iwaardaen, 2013; Dahlgaard, Kristensen, \& Kanji, 2007; Harris, Mccaffer, \& Forwe, 2013) also supported and pointed to four main stages in the evolution of TQM and these were consistent with those identified by (Dale 2003). Total quality management is being used widely in many organizations for some years as a tool to improve the performance of products and services rendered through business, which are very critical maintaining growth and sustenance in the market. This is consistent with the results of (Zaman \& Anjalin, 2016) whom concluded that TQM is used as a strategy to achieve organizational excellence.

To understand TQM, we must offer a definition, but there is no specific standard definition of TQM that exists, various definitions explain the concept, for example, "Total Quality Management may be defined as managing the entire organization so that it excels in all dimensions of products and services that are important to the customer" Chase \& Aquilano, 1992: pp. 186-187 cited in (Miller, 1996; Milakovich, 1990: p. 209) cited in (Psychogios \& Priporas, 2007). It's fair to highlight that TQM is a philospoy where everyone in the organization is involved to mutually produce quality and value for money products and services that meet and exceed the expectations and the needs of customers (Dale, 2003). It's important to highlight the meaning and the significance of the items listed with the abbreviated term TQM to reflect a better understanding. (Al Najjar \& Jawad, 2019: p. 87) defined the abbreviated term TQM, "Total: indicates that quality is the responsibility of all employees of the organization and the various 


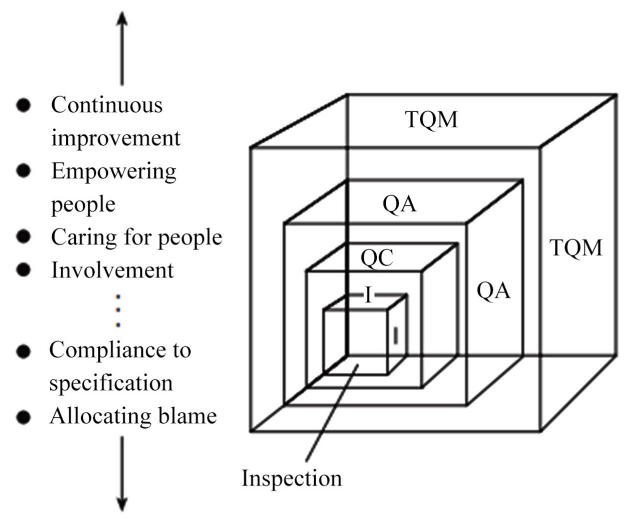

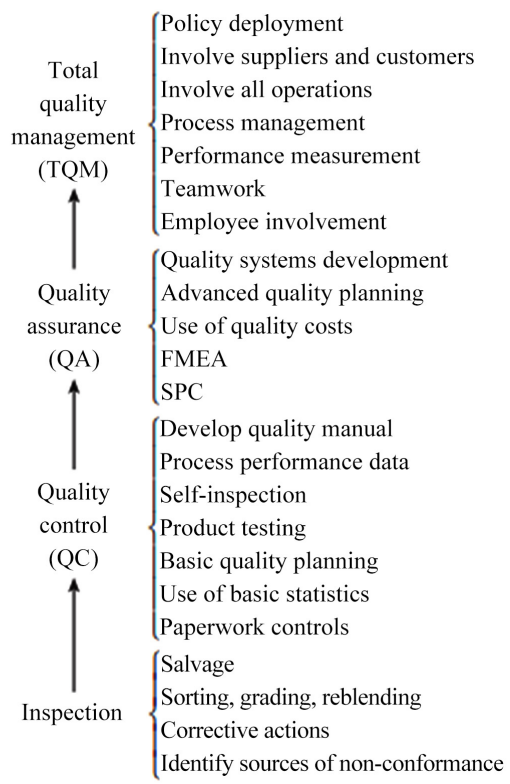

Figure 1. The four levels in the evolution of TQM. (Source: Dale, 2003: p. 21).

activities in it. Quality: refers to achieving and exceeding customer's expectations. Management: refers to planning, organizing, leading, motivating and controlling resources with the aim of continuous improvement".

It's clear that TQM is a management philosophy and a set of guiding principles for managing quality and excellence in an organization to the benefit of all stakeholders (Dale, Wiele, \& Iwaarden, 2013). (Dale, 2003: p. 27) indicated that there are eight principles guiding TQM and they are defined in BS EN ISO9000 (2000) as "Customer focus: Organizations depend on their customers and therefore should understand current and future customer needs, meet customer requirements and strive to exceed customer expectations. Leadership: Leaders establish unity of purpose and direction of the organization. They should create and maintain the internal environment in which people can become fully involved in achieving the organization's objectives. Involvement of people: People at all levels are the essence of an organization and their full involvement enables their abilities to be used for the organization's benefit. Process approach: $A$ desired result is achieved more efficiently when activities and related resources are managed as a process. System approach to management. Identifying, understanding and managing interrelated processes as a system contributes to the organization's effectiveness and efficiency in achieving its objective. Continual improvement. Continual improvement of the organization's overall performance should be a permanent objective of the organization. Factual approach to decision-making. Effective decisions are based on the analysis of data and information. Mutually beneficial supplier relationships. An organization and its suppliers are interdependent and a mutually beneficial relationship enhances the ability of both to create value".

Total quality management (TQM) is a management philosophy to organiza- 
tional performance and excellence through facilitating continual improvement by identifying and eliminating errors happening in production process and taking steps appropriately for streamlining the supply chain network and enhancing and exceeding customer satisfaction by using a process, system approach, factual approach to decision making and the involvement of stakeholders (Luburic, 2015). In reflection of this, (Doulatabadi \& Yousof, 2015 cited in Magd, 2015) provided a simplification of total quality management concept in Table 1.

TQM is recognized as a management approach in achieving organizational excellence and sustainability by encouraging employee feedback and participation, satisfying customers' needs and expectations, respecting social values and beliefs and compliance with governmental regulations (Charantimath, 2011). (Charantimath, 2011) argues that there are five key pillars of TQM (Figure 2), namely product, process, people, system and leadership. The five pillars of TQM adapt the philosophy of continuous improvement which involves all the stakeholders and ensures that customer satisfactions. In reviewing Figure 2, product and process are classified as hard aspects of TQM used to enhance effectiveness, while people and leadership are categorized as soft aspects of TQM used to enhance suitability. On the other hand, the system aspect, which is meant to enhance confluence, as it falls in between the hard and the soft aspects.

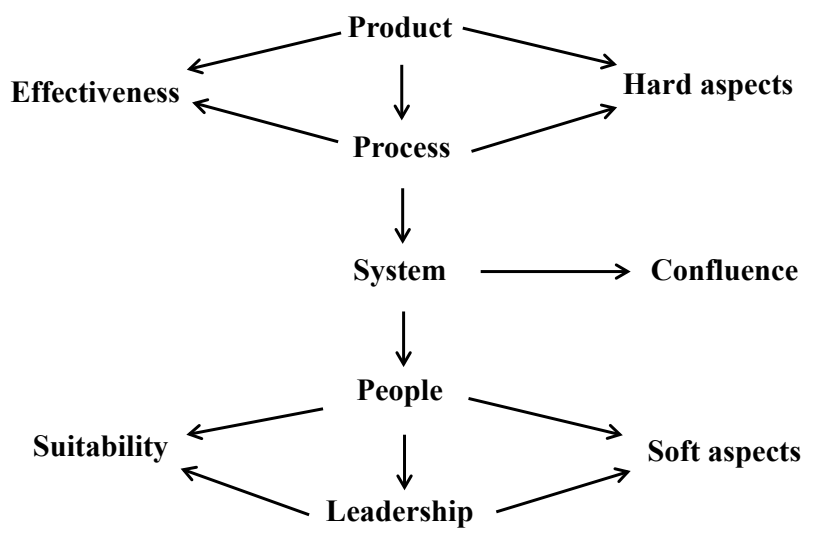

Figure 2. Five key pillars of TQM.

Table 1 . Total quality management concept.

\begin{tabular}{ll}
\hline Concepts & Total Quality Management \\
\hline Philosophy & $\begin{array}{l}\text { To combine people and quality techniques to achieve continuous improvement in } \\
\text { the quality of the product and hence in all aspects of the operation (Harris, 1995) }\end{array}$ \\
Principles & $\begin{array}{l}\text { Customer focused, leadership, involvement, people, process approaches, continual } \\
\text { improvement and supplier relationship }\end{array}$ \\
Process & Statistical Process Control, Plan, Do, Study, Act (PDSA) \\
Performance & $\begin{array}{l}\text { Continuous improvement of the organization, customer satisfaction, and employee } \\
\text { development }\end{array}$ \\
\hline
\end{tabular}

(Doulatabadi \& Yousof, 2015 cited in Magd, 2015: p. 41). 
Much of literature is available on the influence of TQM on organizational performance that is known to bring stability, improvement and business sustenance (Tena, 2004). (Talha, 2004) stated the implications of TQM on manufacturing industry where quality marks a critical component in design for the products to ensure they meet the standards. Large and small organizations irrespective of the business invariably are experiencing the importance to incorporate the TQM tool as part of the business entity, as assurance of maintaining quality and standards and to gain customer satisfaction. Conversely the other facet of TQM apart from its other pillars, includes building on employees' orientation towards quality management through capacity development, training on skill development, coordination and teamwork, scope for knowledge sharing that gives companies an overall approach for continual improvement and sustainable (Hashmi, 2020).

\subsection{Significance of TQM on Organizational Performance, Competitive Advantage and Excellence}

The subject of TQM is widely studied by researchers in different organizations on the influence it has on organizational performance, (Powell, 1995) studied on 15 hypothetical analysis using differing variables revealed that the implementation of TQM in firms has shown success and competitive advantage over non TQM firms though growth and improvement in firms are always not characterized by adopting TQM, analogous to report by (Brah, Wong, \& Rao, 2000). (Terziovski \& Samson, 1999) reports from their hypothetical analysis that TQM and organizational performance are related showing positive effect on operational performance, customer and employee relations and satisfaction but is not uniform across all types of firms considered in their study confirming that adopting TQM facilitates organizations to build employee relations and customer satisfaction which is an indicator to business improvement.

Research findings by (Hassan \& Kerr, 2003) suggested that organizational performance is independent of customer satisfaction and top management in firms where TQM is practiced like findings of (Shrivastava, Mohanty, \& Lakhes, 2006) stating that linkage exists to considerably extent between factors that effects TQM and organizational performance. (Augusto, Lisboa, \& Yasin, 2014) confirms that product and process innovation efforts must promoted by top management, which are essential factors that enhance organizational performance more prominently in smaller firms than larger firms. On the contrary, complex organizational structure and stringent administrative rules existing in firms tend to limit innovation efforts in organizations leading to their poor performance (Valmohammadi, 2012). (Joiner, 2007) affirms that organizational performance has positive correlation to the extent TQM practices are followed in firms which are dependent on organization and co-worker support from top management, confirming with (Douglas \& Judge, 2001 cited in Joiner, 2007). Similar studies by (Sweis et al., 2016) also confirm that TQM practices have a 
great affinity to enhance organizational performance bringing significant improvement in business operations, validating the findings of (Korankye, 2013) that TQM implementation in manufacturing and service organizations significantly presents a competitive advantage in the market.

The successful implementation of TQM in organizations results in achieving competitive advantages (Gharakhani et al., 2013), survival in the fierce business environment, and product/service improvement (Lee, 2004). When examining the relationship between TQM implementation and organizational performance, several studies (Rahman \& Siddiqui, 2006; Joiner, 2007; Das, Paul, \& Swierczek, 2008; Sila, 2007; Chin \& Pun, 2002) concluded that there is strong positive correlation between TQM practices implementation and organizational performance. Moreover, other studies confirmed that there is a positive relationship between the effective implementation of TQM practices and operational performance (Tan, 2013; Shafiq, Lasrado, \& Hafeez, 2019; Al-Serhan, 2019). Other documented benefits from TQM implementations are improved financial performance (Moballeghi \& Moghaddam, 2011; Kristian \& Panjaitan, 2014; Gharakhani et al., 2013; Ngambi \& Nkemkiafu, 2015), customer satisfaction (Yazdani et al., 2013; Besterfield et al., 2012), and employee satisfaction (Peris-Ortiz, Garcia, \& Armengot, 2015; Ismail Salaheldin, 2009; Chapman \& Al-Khawaldeh, 2002); improved communication (Bubshait, 2007), and reduced waste and defects (Kaynak \& Rogers, 2013). In support of the positive impact of TQM is supported further by the statement made by (Chin \& Pun, 2002: p. 273) whom claimed that the implementation of TQM can generate improved products and services, reduced costs, more satisfied customers and employees, and improved bottom line financial performance.

\subsection{TQM Practices and Performance: Manufacturing and Service Organisations}

Manufacturing and service organizations are the two largest global industrial sectors with the former holding operations involving production through preparation of products from raw materials, processing and marketing of the finished product to the consumer in the market and the latter having operations providing end user services to customers (Talib \& Rahman, 2012). Manufacturing and service organizations have similarities and differ in the way business operations are carried out by them (Jiang, 2009). Manufacturing and service organizations have taken a hypothetical shift towards sustainable practices in business production to overcome prevailing challenges. (Eslami et al., 2019) studied on achieving sustainability through a three-dimensional approach in manufacturing industries to understand the contribution of each dimension on sustainable ways of production. Literature studies described by Hassan \& Kerr, 2003 concludes that quality practices implemented in service organizations are known to improve organizational performance bringing in productivity, increasing financial outputs, customer satisfaction by proper scheduling of deliveries in service sector 
industries, results confirming to studies by (Prajogo \& Brown, 2006; Lakhal, Passin, \& Limam, 2006; Duarte et al., 2011).

(Prajogo \& Sohal, 2003) conclusions are worth mentioning in conjunction to the findings of other researchers on TQM practices, they highlighted that these quality management practices in manufacturing firms have positive effect on organization performance principally improvising product quality, process and product innovation. These results are consistent to reports of (Deming, 1982; Juran, 1988 cited in O’Neill, Sohal, \& Teng, 2016) besides coinciding with the studies of (O'Neill, Sohal, \& Teng, 2016). Analyzing the previous studies of researchers, it is impressive to comprehend that majority of manufacturing and service organizations currently are emphasizing efforts to incorporate TQM practices at every stage of business operation for achieving better performance through maintaining quality in product and services. In this context, organizations are imperative to consistently evaluate and measure their business success with reference to maintaining competitive stature in the market agreeing to studies by (Rahman \& Bullock, 2005) who conducted studies applying different dimensional approach using soft and hard TQM elements to measure organizational performance in manufacturing firms, whose results point to soft and hard TQM elements to different degrees showing the positive relationship with organizational performance likewise confirming with other studies of (Powell, 1995; Dow, Samson, \& Ford, 1999).

Maintaining product quality and efficiency in service provision are focal to these organizations to register progressive growth in business performance and sustain competition in the market, which can be succeeded by implementing TQM in manufacturing and service firms (Jancikova \& Brychta, 2009). However, studies by (Beamount et al., 1997 cited in (Prajogo, 2005) concluded that the level of TQM implementation is lower in service organisations than manufacturing firms similar to the findings reported by (Woon, 2000) while this validation instrument is tested in manufacturing sector extensively by (Ahire, Golhar, \& Waller, 1996; Dow, Samson, \& Ford, 1999; Flynn, Schroeder, \& Sakakibara, 1994; Samson \& Terziovski, 1999) indicating a strong implementation of quality elements in manufacturing firms against service organizations. Further studies by (Huq \& Stolen, 1998) substantiates to the previous observations and concluding that TQM elements in service sectors are partially enforced unlike manufacturing firms that apply full range of TQM practices, thus experience higher performance over service sectors, which contradict to the findings of (Talib \& Rahman, 2012) indicating that the level of TQM practices in manufacturing and service sectors have no significant difference except in three practice elements implying that the extent of TQM practices remains balanced in both the organizations.

\subsection{TQM and Organizational Sustainability Relationship}

TQM practices in organizations are becoming benchmarks for business susten- 
ance and success is reciprocated in the strength of relationship and the extent of quality management practices in every organization. Extensive studies in this area reveal that TQM practices tend to facilitate organizations in maintaining consistent growth in business through improved quality of products and services, comparable to studies from (Al Harbi, Al Matari, \& Yusoff 2016) that TQM implementation in organizations have affinity to result in sustainable growth and the two constructs share positive relationship. However, (Robson, Prabhu, \& Mitchell, 2002) argued total quality enablers identified specific to each organization will guide how these enablers influence achieving sustainability in organizations realistically. On the other hand, (Isaksson, 2006) reviewed various models in conjunction with their previous literature (Isaksson \& Garvare, 2003) on TQM and sustainability, justifying that organizations can realize success through focus on process development in organizations.

Conversely (Sebastianelli \& Tamini, 2003) identified through their study set of obstacles that often hinder TQM success in organizations and those obstacles serve as potential barriers laterally for sustainable growth and business success. Despite these claims, success cannot translate or drive organizations totally into being sustainable where both these constructs are timebound and spatially related, analogous to study supplemented by (Aquilani, Silvestri, \& Ruffiwei, 2016); who has reviewed papers of (Karuppusami \& Gandhinathan, 2006; Yusof \& Aspinwall, 1999; Wali, Deshmukh, \& Gupta, 2003; Claver, Tari, \& Molina, 2003; Seetharaman, Srinivasan, \& Boon, 2006; Ismail Salaheldin, 2009) on critical success factors (CSF) testifying these factors have significant role in propelling TQM implementation and effective adoption of TQM practices would eventually facilitate organizations achieve success. Further reports on TQM influence on organizational sustainability were studied by (Lee, McLee, \& Huang, 2011; Dóci \& Hofmans, 2015) that transformational leadership has larger influence on sustainable competitive advantage in organizations while (Chen, Lee, \& Wang, 2020) projected IPO (input-process-output) model to translate TQM in organizations for improving performance.

\subsection{TQM Implementation Barriers}

TQM implementation has been challenged in developed and developing countries due to different barriers which hinder the effective implementation of TQM. It's essential to understand TQM implementation barriers where effective strategies can be developed for the successful implementation of TQM (Jacobsen, 2008) in the manufacturing and service sector. Having an insight into TQM barriers would enable managers to take a proactive role in preventing the rise of such barriers and help in the effective TQM implementation. In view of this, the authors will offer several studies on TQM implementation barriers in different countries.

(Rad, 2006) determined TQM implementation barriers in Iran which included lack of teamwork, poor management control, inadequate response to customer 
requirements, resistance to cultural change and environmental changes. In $\mathrm{Pa}$ kistan, (Awan et al., 2009) found that lack of top management support and commitment was a major barrier for TQM Implementation. Another study from Pakistan by (Khan, 2011) indicated that resistance to change, lack of employee training, lack of resources, and lack of empowerment were the most significant barriers to TQM implementation. A study by (Amar \& Zain, 2001) conducted on the ineffectiveness of TQM implementation in Indonesia, and determined that management attitudes, training and education, organizational culture, human resources and inter functional relationships were the major barriers for ineffective TQM implementation.

In Malaysia, (Shaari, 2010) determined the TQM implementation barriers to be lack of management commitment, implementation costs, lack of understanding the TQM concept. While in UK and Australia the barriers were poor communication, inadequate resources, and lack of commitment. In the USA, (Sebastianelli \& Tamimi, 2003) indicated that lack of customer focus, weak leadership and commitment, inadequate human resources, and inadequate organizational infrastructure were the prominent barriers. While (Jun, Cai, \& Peterson, 2004) added that lack of employee training, lack of compensation and employee resistance were additional barriers identified in the USA.

TQM Implementation barriers in Turkey were identified by (Polat, Damci, \& Tatar, 2011) as poor leadership, and lack of top management commitment. Within the same context, (Sadikoglu \& Olcay, 2014) revealed that lack of resources, lack of employee participation, lack of awareness and understanding of TQM philosophy. This is supported further by a study performed in India by (Bhat \& Rajashekhar, 2009; Johnson, 2013). A comprehensive study conducted by (Mosadeghrad, 2014) analyzing 54 TQM empirical studies in 23 countries on TQM implementation and the study revealed the most significant barriers were lack of top management commitment, lack of financial resources, lack of training and education, lack of communication, lack of employee participation, resistance to change, poor delegation, and poor quality culture. In the same vein, (Berrouiguet, 2013) identified four major barriers in Algeria and they lack top management support, lack of employee knowledge and skills, cultural change and lack of financial support. In Egypt, (Ismail Salaheldin, 2003) found that employee resistance, poor training, insufficient infrastructure and lack of employees' knowledge and skills. (Alsughayir, 2014) examined TQM barriers in Saudi Arabia and indicated that lack of understanding of TQM, lack of motivation, and high turnover were the barriers for TQM implementation. Another study was conducted in Yemen, where the barriers were inadequate support for TQM, lack of managerial experience with TQM, and cultural challenges ( $\mathrm{Al} \mathrm{Za-}$ many, Hoodle, \& Savage, 2002). (Twaissi, Rollins, \& Worsdale, 2008) investigated TQM implementation in Jordanian information and communications technology sector and revealed that weak quality organizational culture, lack of continuous improvement and lack employee empowerment were barriers to 
TQM implementation. In support of the above studies, the authors compiled the most common TQM barriers reported in the literature review (Table 2) which prevent effective implementation of TQM.

\section{Discussion}

TQM in organizations has become an identity for success in many firms irrespective of the nature, type and locations, nevertheless largely the results shows no significant discrimination of benefits accrued by TQM firms from those of non-TQM firms. However, TQM practices possibly create economic value to the firm but that again depends on certain specific factors effecting in improving performance in manufacturing and service sectors differently (Powell, 1995).

Analyzing the results from various research studies where TQM shows a distinctive advantage in general to firms though not necessarily providing superior quality and profitability of business but on the contrary gives better product services through ensuring customer satisfaction. Studies done in manufacturing firms shows, TQM known to have an indirect effect on organizational performance from prevailing supportive environment provided by organization and co-workers would eventually enhance the performance inferring that business growth is embedded to the entities within an organization.

Table 2. Common TQM barriers.

\begin{tabular}{|c|c|c|}
\hline \multicolumn{2}{|c|}{ Common TQM Barriers } & \multirow{2}{*}{$\begin{array}{l}\text { Studies from Literature Review } \\
\text { Sebastianelli and Tamimi (2003); Shaari (2010), Burcher et al. (2010), Polat et al. (2011), } \\
\text { Mosadeghrad (2014), Awan et al. (2009), Al-Khalifa and Aspinwall (2000), Al Zamany et al. } \\
\text { (2002), Berrouiguet (2013) }\end{array}$} \\
\hline 1 & $\begin{array}{l}\text { Lack of Top Management/Leadership } \\
\text { Commitment }\end{array}$ & \\
\hline 2 & $\begin{array}{l}\text { Lack of Human Resources Management } \\
\text { and Development }\end{array}$ & $\begin{array}{l}\text { Jun et al. (2004), Nwabueze (2001), Johnson (2013), Mosadeghrad (2014), Amar and Zain } \\
\text { (2001), Khan (2011), Ismail Salaheldin (2003), Bhat and Rajashekhar (2009), Twaissi et al. } \\
\text { (2008), Osuagwu (2002), Sadikoglu and Olcay (2014), Salegna and Fazel (2000), } \\
\text { Sebastianelli and Tamimi (2003), Al Zamany et al. (2002), Cătălin et al. (2014), Bayazit (2003) }\end{array}$ \\
\hline 3 & Resistance to Change & $\begin{array}{l}\text { Jun et al. (2004), Nwabueze (2001), Johnson (2013), Mosadeghrad (2014), } \\
\text { Ismail Salaheldin (2003), Bhat and Rajashekhar (2009), Salegna and Fazel (2000), } \\
\text { Sebastianelli and Tamimi (2003), Alsughayir (2014), Talib et al. (2011), } \\
\text { Al-Khalifa and Aspinwall (2000), Berrouiguet (2013) }\end{array}$ \\
\hline 4 & $\begin{array}{l}\text { Lack of Understanding and Awareness } \\
\text { of TQM }\end{array}$ & $\begin{array}{l}\text { Shaari (2010), Sadikoglu and Olcay (2014), Ismail Salaheldin (2003), Berrouiguet (2013), } \\
\text { Alsughayir (2014), Al-Marri et al. (2007), }\end{array}$ \\
\hline 5 & Poor Communication & Burcher et al. (2010), Mosadeghrad (2014) \\
\hline 6 & Lack of Customer Focus & Rad (2006), Sebastianelli and Tamimi (2003) \\
\hline 7 & Lack of Teamwork & Kumar et al. (2011), Cătălin et al. (2014), Mosadeghrad (2014) \\
\hline 8 & $\begin{array}{l}\text { Inadequate Resources (Human, physical, } \\
\text { infrastructure, Financial, information) }\end{array}$ & $\begin{array}{l}\text { Burcher et al. (2010), Johnson (2013), Khan (2011), Ismail Salaheldin (2003), } \\
\text { Sadikoglu and Olcay (2014), Berrouiguet (2013), Mosadeghrad (2014), Cătălin et al. (2014) }\end{array}$ \\
\hline 9 & Organizational Culture & Twaissi et al. (2008), Amar and Zain (2001), Rad (2006) \\
\hline 10 & Lack of Continuous Improvement & Mosadeghrad (2014), Talib et al. (2011), Twaissi et al. (2008) \\
\hline
\end{tabular}


Globally both large and small firms continually strive for improving organizational performance to gain excellence in this competitive market, should necessarily focus on product and process innovation in all the business operations, however innovation to product and process involves top management commitment to determine the innovative mechanism are effective towards enhancing organizational performance. Contrary to this belief, organizational performance in both sectors are dependent to the extent the TQM practices are implemented within each organization addition to the other inputs elements for business operation. Moreover, effective implementation of TQM is depended on the identification of potential barriers where the management team can take a proactive approach in preventing the existence of such barriers or obstacles and help in the effective TQM implementation.

In fact, organization performance and sustainable business growth irrespective of nature of firm are not always characteristic influences of TQM practices, nonetheless varied entities with each organization should be augmented to achieve an overall business sustenance. While it is worth noting to infer that top management is the critical key factor for driving the TQM practices in every organization and the concurrent success depends on the organization culture and management commitment to support business growth. While evidence from research studies proved that performance in organizations is directly proportional to the extent of TQM practiced in organizations this is not universally the trend observed in all the organizations, with lesser levels of implementation in service organizations than manufacturing firms which is due to the reason that every organization is characterized by its type of business entities, volume of operations carried out and the nature of work.

From the considerable development organizations are making towards improving quality and sustain business continuity, ironically without sustainability as core value, the TQM initiatives might prove unsuccessful in improving organizational performance though significant empirical studies advocates that TQM will improve organizations performance (Zakuan et al., 2010). In conclusion, improved performance, business sustainability in organizations can be achieved if there is better management of TQM practices.

\section{Proposed Model of TQM Practices for Sustaining Organization Performance in Manufacturing and Service Sectors}

TQM practices are widely studied by various researchers in both manufacturing and service sectors and those studies reveals that TQM practices will enhance organization performance that will subsequently build business sustenance and growth over time (Fuentes, Montes, \& Fernandez, 2006; Martínez-Costa et al., 2009; Idris \& Zairi, 2006; Rahman \& Bullock, 2005; Lin et al., 2005; McAdam \& Bannister, 2001; Sila, 2007; Temtime \& Solomon, 2002). Extensive review of studies by various researchers on TQM only reveals, there are no specific studies conducted to find the specific TQM constructs or dimensions that indicate or- 
ganizational performance in manufacturing and service sectors except partial studies related to TQM practices on organizational performances. Therefore, the authors have worked to identify the TQM constructs referring to different studies done by various researchers on manufacturing and service sectors to the extent these practices are effective approaches to enhance the organization performance. There is dearth of standard pathways and conceptual framework for manufacturing and service organizations currently to adopt, which can guide practitioners, managers and decision makers to use these models for sustaining organization performance. Empirical studies show that TQM practices have positive correlation with organizational performance resulting in significant improvement in business operations. Different researchers (Oza \& Shiroya, 2015; Sureshchandar et al., 2002; Talib \& Rahman, 2012; Rad, 2005; Karuppusami \& Gandhinathan, 2006; Bartley, Gomibuchy,\& Mann, 2007; Chowdhury, Paul, \& Das, 2007; Abdullah, Uli, \& Tari, 2008) have identified variable number of TQM constructs that were known to be implemented largely in manufacturing and service sectors (Table 3 and Table 4). Organizations to experience sustainable growth in performance must identify certain key TQM elements that are critical for improvement in organizations and adopting those practices in organizations will show better performance from those that do not (Powell, 1995). To this effect, identifying the key contributing TQM factors for organization performance remains a challenge in view of limited studies done and published by researchers, however only few published empirical studies have indicated specific TQM constructs that have significant effect on improving organization performance, that are identified in this study and presented in Table 5. Further to understand the key TQM elements leading to organization performance published by various researchers are compared in Table A1 and the frequency of key TQM elements occurring in various reported studies are captured that are significant to organizations performance and is graphically represented in Figure 3.

Performance measurement in organizations are result of adopting both hard and soft TQM Performance measurement in organizations are result of adopting both hard and soft TQM elements that produce tangible and intangible results to business, quality, operation and sustenance. Various researchers from their analysis on TQM indicate that soft TQM elements tend to affect hard TQM elements, while each of them invariably have significant correlation with organizational performance, based on this hypothetical approach a conceptual framework considering the soft and hard TQM elements that leads to organization performance is described in Figure 4. Further to the studies published by various authors shows some of the soft and hard TQM elements are observed to be common to manufacturing and service sectors conceived through this study are presented in Figure 5.

From the analysis of literature on the various studies published on TQM practices, the authors have developed a model pathway (Figure 6) that can be adopted by practitioners and managers in manufacturing and service sectors as 
an approach to achieve organizations performance. Performance is a dependable variable and function of quality, business, sustainability and operation activities that are linked to the outcomes of TQM practices which are independent variables (Hassan et al., 2012).

Table 3. Analysis of literature on TQM practices in manufacturing sector.

\begin{tabular}{ll}
\hline Author(s)/year of study & TQM practices \\
\hline Talib \& Rahman, 2012 & $\begin{array}{l}\text { Top management commitment, customer focus and satisfaction, training and education, human resource } \\
\text { management, supplier management, process management, employee involvement, quality systems, quality } \\
\text { information and performance measurement. }\end{array}$
\end{tabular}

Zhang et al., 2000

Top management commitment, process improvement, product design, training and development, supplier relationship management, customer satisfaction, employee empowerment, employee involvement, information and analysis, quality citizenship.

Prajogo \& Sohal, 2003

Leadership, strategic planning, customer focus, information and analysis, people management, process management, product quality, product innovation, process innovation.

Singh et al., 2018

Organizational leadership, customer satisfaction, human resource focus, strategic planning and development, supplier quality management, satisfaction results, business results.

Agus \& Abdullah, 2000

Executive commitment, customer focus, supplier relations, quality training, employee focus, quality measurement

Quek \& Yusof, 2003

Zakuan et al., 2010

Management leadership, continuous improvement, customer satisfaction, improvement tools and techniques, supplier quality management, employee participation, education and training, work environment.

Quality leadership, customer focus and satisfaction, quality information and analysis, human resource development, strategic planning management, supplier quality management, quality results, quality assurance.

Mission statement, customer focus, management commitment, worker empowerment, communications,

Huq \& Stolen, 1998 performance appraisal system, statistical evidence of quality, familiarity with TQM, measures of costs, causes of quality, continual improvement, problem solving approach, education and training, supplier development, quality improvement.

Kumar et al., 2011

Management commitment, customer satisfaction, continuous improvement, teamwork, employee's empowerment, training, feedback, and effective communication.

Customer focus, leadership, design quality, speed and prevention, people participation and partnership, strategic quality planning, continuous improvement, fact-based management

Management commitment, customer focus, supplier management, employee training, employee empowerment, employee involvement, information and analysis, product and service design.

Top management commitment, employee involvement, customer focus, fact-based management, incentive and recognition system process, monitoring and control, continuous improvement.

Leadership, strategic planning, customer focus, information and analysis, people management, process management, and product quality.

Top management commitment, customer focus and satisfaction, supplier management, training and education,

Talib et al., 2011 human resource management, process management, quality systems, employee involvement, quality information and performance measurement.

Feng et al., 2006

Leadership, strategic planning, customer focus, information and analysis, people management, process management, product quality, product innovation.

Top management commitment, customer focus, employee training, benchmarking, internal quality, employee empowerment, employee involvement, design quality, product quality, supplier management, information and analysis. 
Table 4. Analysis of literature on TQM practices in service sector.

\begin{tabular}{ll}
\hline Author(s)/year of study & TQM practices \\
\hline Hassan \& Kerr, 2003 & $\begin{array}{l}\text { Top management, customer satisfaction, employee involvement, quality cost, service design. } \\
\text { Total employee involvement, continuous improvement, continuous training, teamwork empowerment, } \\
\text { Psychogios \& Priporas, 2007 } \\
\text { top-management commitment and support, democratic management style, customer/citizen satisfaction, } \\
\text { culture change } \\
\text { Orgh et al., 2018 }\end{array} \quad \begin{array}{l}\text { Organizational leadership, customer satisfaction, human resource focus, strategic planning and development, } \\
\text { supplier quality management, satisfaction results, business results }\end{array}$
\end{tabular}

Huq \& Stolen, 1998

Mission statement, customer focus, management commitment, worker empowerment, communications, performance appraisal system, statistical evidence of quality, familiarity with TQM, measures of costs, causes of quality, continual improvement, problem solving approach, education and training, supplier development, quality improvement.

Kumar et al., 2011

Management commitment, customer satisfaction, continuous improvement, teamwork, employee's empowerment, training, feedback, and effective communication

Pino, 2008

Management commitment, customer focus, supplier management, employee training, employee empowerment, employee involvement, information and analysis, product and service design.

Top management support, customer focus, employee involvement, employee training, employee

Brah et al., 2000 empowerment, supplier quality management, process improvement, service design, quality improvement, benchmarking, cleanliness and organization.

Prajogo, 2005

Leadership, strategic planning, customer focus, information and analysis, people management, process management, and product quality

Samat et al., 2006

Management support and commitment, employee involvement, employee empowerment, information and communication, training and education, customer focus, continuous improvement.

Top management commitment, customer focus and satisfaction, continuous improvement and innovation,

Talib et al., 2011 human resource management, training and education, employment involvement, benchmarking, quality culture, supplier management

Black \& Porter, 1996

People and customer management, supplier partnerships, communication of improvement information, customer satisfaction orientation, external interface management, teamwork, operational quality planning, quality improvement measurement systems, corporate quality culture.

Top management commitment, human resource management, technical system, information and analysis system, benchmarking, continuous improvement, customer focus, employee satisfaction, union intervention, social responsibility, service culture.

Management commitment, role of the quality department, training and education, employee involvement, reporting, communication to improve quality, and customer satisfaction orientation.

Table 5. Research studies on TQM and organizational performance reported in literature.

\begin{tabular}{lll}
\hline Author(s)/year of study & Topic of study & Key TQM practices for organization performance \\
\hline Powell, 1995 & $\begin{array}{l}\text { Total quality management as competitive advantage: } \\
\text { a review and empirical study }\end{array}$ & $\begin{array}{l}\text { Top management commitment, employee empowerment, } \\
\text { open organization. }\end{array}$ \\
Choi \& Eboch, 1998 & $\begin{array}{l}\text { The TQM Paradox: Relations among TQM practices, } \\
\text { plant performance, and customer satisfaction }\end{array}$ & $\begin{array}{l}\text { Process quality, HRM, strategic quality planning, } \\
\text { information and analysis }\end{array}$ \\
Dow et al., 1999 & $\begin{array}{l}\text { Exploding the myth: Do all quality management practices } \\
\text { contribute to superior quality performance? }\end{array}$ & Customer focus, shared vision, workforce commitment. \\
\hline
\end{tabular}




\section{Continued}

Rahman \& Bullock, 2005

Prajogo \& Sohal, 2003

Terziovski \& Samson, 1999

Motwani, 2001

Feng et al., 2006

Brah et al., 2000

Hassan \& Kerr, 2003

Samson \& Terziovski, 1999

Shafiq et al., 2019

Malik et al., 2010

Chong \& Rundus, 2004

Fotopoulos \& Psomas, 2009

Hassan et al., 2012

Rahman, 2001

Pambreni et al., 2019
Soft TQM, hard TQM, and organizational performance relationships: an empirical investigation

The relationship between TQM practices, quality performance, and innovation performance: An empirical examination.

The link between total quality management practice and organisational performance

Critical factors and performance measures of TQM

The impact of TQM practices on performance: A comparative study between Australian and Singaporean organizations

Relationship between TQM and Performance of Singapore Companies.

The relationship between total quality management practices and organizational performance in service organizations.

The relationship between total quality management practices and operational performance.

The effect of TQM on organizational performance: empirical evidence from the textile sector of a developing country using SEM.

TQM Practices \& Organizational Performance: Evidence from Pakistani SMEs.

Total Quality Management, Market Competition and Organizational Performance.

The impact of "soft" and "hard" TQM elements on quality management results.

Impact of TQM Practices on Firm's Performance of Pakistan's Manufacturing Organizations

A comparative study of TQM practice and organizational performance of SMEs with and without ISO 9000 certification.

The influence of total quality management toward organization performance
Workforce commitment, shared vision, customer focus, use of teams, cooperative supplier relations, JIT, technology utilization, continuous improvement.

Leadership, customer focus, information and analysis, people management, process management, strategic planning.

Leadership, customer focus, information and analysis, process management, people management, strategic planning management.

Top management commitment, quality measurement and benchmarking, process management, product design, employee training, employee empowerment, customer involvement, supplier management.

Leadership, HRM, customer focus, process management. Top management, employee empowerment, employee involvement, customer focus, quality improvement.

Top management commitment, employee involvement, training, supplier quality, quality cost, service design, quality techniques, benchmarking, customer satisfaction.

Leadership, HRM, customer focus.

Leadership, process management, HRM, strategic planning.

Top management commitment, customer focus, supplier relationships, employee involvement, employee empowerment, benchmarking, work environment.

Customer focus, product design.

Adoption of hard and soft TQM will improve organization performance

Commitment to quality, employee involvement, customer focus, fact-based management, process monitoring and control, incentive and recognition system, continuous improvement.

Leadership, Information and analysis, strategic planning, people management, customer focus, processes/products services.

Customer focus, continuous improvement, strategic planning, employee involvement.

All firms to improve their performance successfully and achieve business sustainability must go through four phases in the model pathway like the process of PDCA followed in management system implementation. 


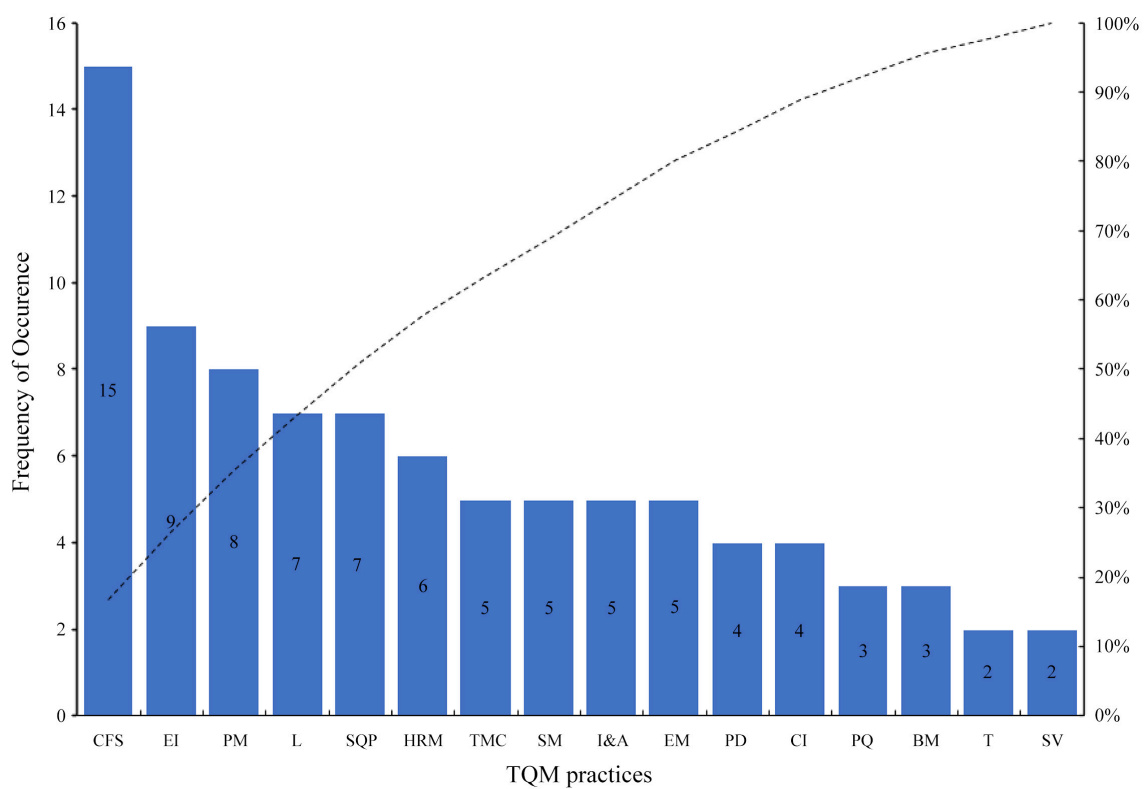

Figure 3. Frequency of occurrence of key TQM practices significant to organizational performance.

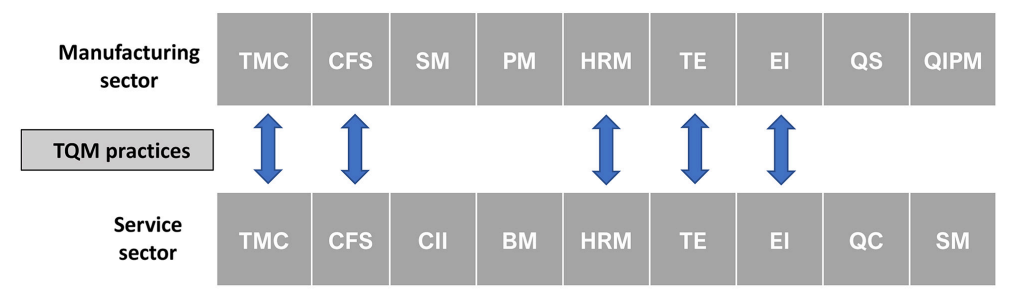

Figure 4. TQM practices common in manufacturing and service organizations reported by various authors. Source: Talib and Rahman, 2012.

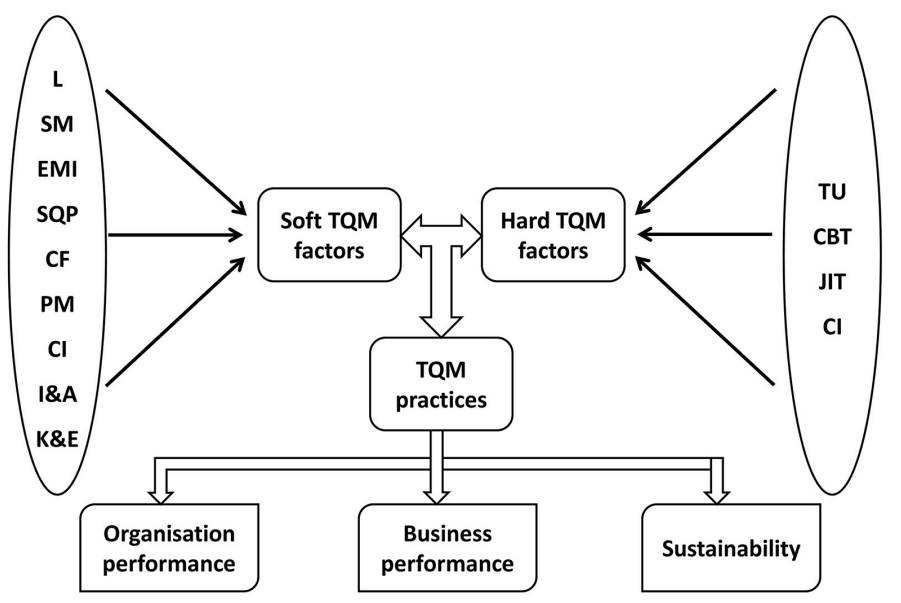

Figure 5. Conceptual framework of TQM practice approach towards sustaining organizational performance. Source: Saleh et al., 2018. L = leadership, SM = supplier management; $\mathrm{EMI}=$ employee management \& involvement; $\mathrm{CF}=$ customer focus; $\mathrm{PM}=$ process management; $\mathrm{CI}=$ continuous improvement; $\mathrm{I} \& \mathrm{~A}=$ information $\&$ analysis; $\mathrm{K} \& \mathrm{E}=$ knowledge \& education; TU = technology utilization; CBT = computer-based technologies; JIT $=$ just in time; $\mathrm{CI}=$ continuous improvement. 


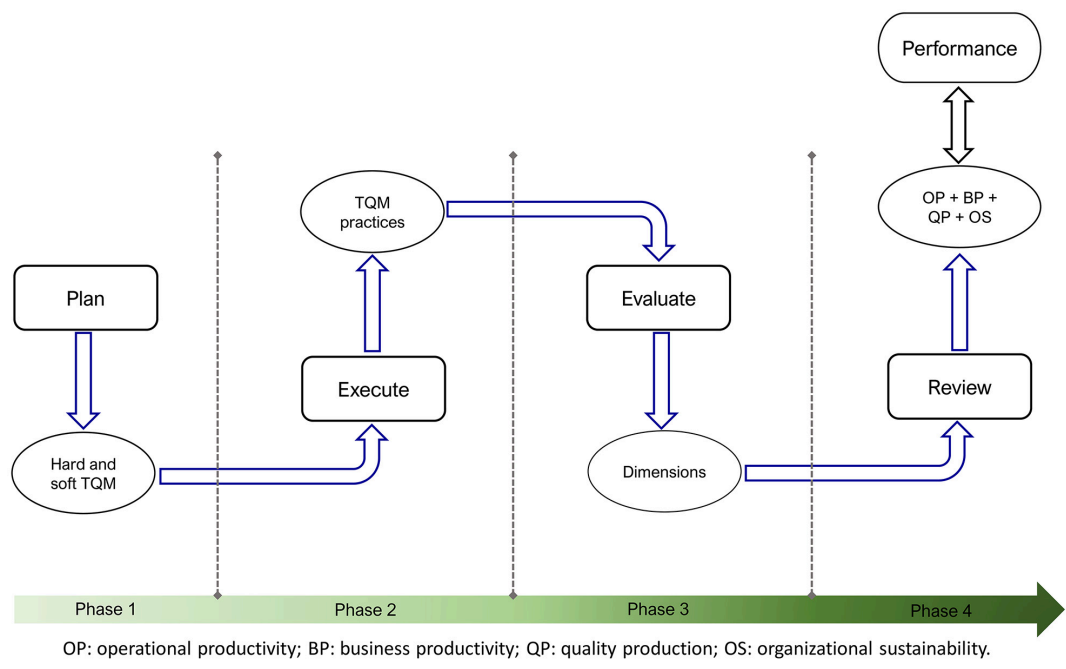

Figure 6. Proposed TQM model pathway for organizational performance and sustainability in manufacturing and service sectors.

First Phase-Planning Phase: organizations have to assess its internal capability, and its available resources in order to be developed and allocated such as development of quality policy, identification or organizational structure to support TQM, dynamic leadership as stated in hard and soft TQM factors. Additionally, organizations should initiate and build awareness among organizational internal stakeholders of TQM as a strategy for organizational performance. The management team identify potential TQM barriers that may hinder the implementation of TQM and prevent such barriers from occurring in support of TQM implementation. Moreover, organizations must identify TQM practices combining hard and soft factors/constructs that enable the organization to achieve superior performance as depicted in Table 3.

Second Phase-Execution/implementation phase: in this phase, organization initiate the execution phase regarding the specific TQM factors/constructs considering the management support and feasibility to organization culture to support the effective implementation of TQM. For example, training programs to prepare employees for the implementation of TQM.

Third Phase-Sustainability Phase through Evaluation and Review: in the phase of evaluation, organization must consider the evaluation of those TQM dimensions to assess the quality and innovation in process and product.

Fourth Phase-Review: Finally, in the evaluation phase which involves a review of the effect of TQM practices on the quality, business and operation to measure their organizational performance and sustainability.

During the execution of different phases of the model pathway, firms need to focus more specifically on key TQM dimensions that have more frequency of occurrence significant to organizational performance.

\section{Conclusion}

Total quality management has gained more importance and prominence in al- 
most every business today. With the growing business competition among different industrial sectors, there is every need that organizations must maintain sustainability and improve their performance with increasing industrialization especially expansion of manufacturing and service sectors in the modern world. To thrive over the global competitive market, TQM is perceived to show significant impact on the business continuity, sustainability and organization performance and in order to achieve the benefits of TQM, establishments specifically manufacturing, and service sectors have to thoroughly understand the concepts underlying to implement the management system.

However, to achieve the targets, there are certain barriers that are inherent to every business which prevents the implementation of TQM practices in organizations. Some of them lack of top management commitment, resistance to change, lack of customer focus, poor organizational culture, lack of proper human resource management etc. which ultimately does not permit establishment to achieve their full potential in terms of performance, improvement and sustainability. While most of the organizations currently have involved TQM system and successfully implemented the concepts in their business operations, yet there are set of critical TQM practices known to significantly influence organization performance with reference to manufacturing and service sector establishments, including customer focus and involvement, employee involvement and workforce commitment and process management which are very critical for achieving organization performance and sustainability in business. Addressing these practices will not effectively overcome the TQM barriers organizations have but implementing the key TQM dimensions and factors specific to each type of industry will overcome the challenges and leads establishments to achieve sustainability and improves performance.

Further, the proposed conceptual framework and TQM model pathway developed through the study provides directional guidance to mangers, decision makers and managements of manufacturing and service sector establishments to achieve sustainability and improving organization performance from implementing TQM approach through the four phased process. Within this model, approach establishments should also strive to emphasize on the specific TQM dimensions that are characteristic to their nature of business and scale of operation that varies from organization to organization.

\section{Limitations and Future Scope}

The study is comprehensive in nature, but we believe that one of the major limitations in the current study is mainly the focus on secondary data collection and no primary data was considered in verifying the proposed model; thus, this study offers several future avenues for research. Future studies may focus on validating and empirically testing the proposed model for achieving organizational performance and sustainability in manufacturing and service sectors. Additionally, other studies may focus on testing the model in different contexts (coun- 
tries and regions) and sectors (either service or manufacturing or both).

\section{Acknowledgements}

The authors would like to thank Modern College of Business and Science management and particularly thank the Dean, Dr. Khalfan Al Asmi for encouraging to pursue the research work.

\section{Conflicts of Interest}

The authors declare no conflicts of interest regarding the publication of this paper.

\section{References}

Abdullah, M. B., Uli, J., \& Tari, J. J. (2008). The Influence of Soft Factors on Quality Improvement and Performance: Perceptions from Managers. The TQM Magazine, 20, 436-452. https://doi.org/10.1108/17542730810898412

Agus, A., \& Abdullah, M. (2000). Total Quality Management Practices in Manufacturing Companies in Malaysia: An Exploratory Analysis. Total Quality Management, 11, 1041-1051. https://doi.org/10.1080/095441200440313

Ahire, S. L., Golhar, D. Y., \& Waller, M. W. (1996). Development and Validation of TQM Implementation Constructs. Decision Sciences, 27, 23-56. https://doi.org/10.1111/j.1540-5915.1996.tb00842.x

Al Harbi, K., Al Matari, E. M., \& Yusoff, R. Z. (2016). The Impact of Total Quality Management (TQM) on Organisational Sustainability: The Case of the Hotel Industry in Saudi Arabia: Empirical Study. The Social Sciences, 11, 3468-3473.

Al Najjar, S., \& Jawad, M. (2019). Total Quality Management Practices and Impediments in the Arab Countries with Special Reference to Iraq. Journal of Law and Society Management, 6, 86-96.

Al Zamany, Y., Hoddle, S. E., \& Savage, B. M. (2002). Understanding the Difficulties of Implementing Quality Management in Yemen. The TQM Magazine, 14, 240-247. https://doi.org/10.1108/09544780210429852

Al-Khalifa, K. N., \& Aspinwall, E. M. (2000). The Development of Total Quality Management in Qatar. The TQM Magazine, 12, 194-204.

https://doi.org/10.1108/09544780010320250

Al-Marri, K., Moneim, M., Baheeg Ahmed, A., \& Zairi, M. (2007). Excellence in Service: An Empirical Study of the UAE Banking Sector. International Journal of Quality \& Reliability Management, 24, 164-176. https://doi.org/10.1108/02656710710722275

Al-Serhan, A. (2019). Impact Assessment of Total Quality Management on Firm Performance: Evidence from Pharmaceutical Companies of Jordan. Asian Journal of Applied science and Technology, 3, 254-265.

Alsughayir, A. (2014). Does Practicing Total Quality Management Affect Employee Job Satisfaction in Saudi Arabian Organizations? European Journal of Business and Management, 6, 169-175.

Amar, K., \& Zain, Z. M. (2001). Barriers in the Implementation of Total Quality Management in Indonesian Manufacturing Organisations. Jurnal Teknik Industri, 3, 72-79.

Antony, J., Leung, K., Knowles, G., \& Gosh, S. (2002). Critical Success Factors of TQM Implementation in Hong Kong Industries. International Journal of Quality \& Reliabil- 
ity Management, 19, 551-566. https://doi.org/10.1108/02656710210427520

Aquilani, B., Silvestri, C., \& Ruggieri, A. (2016). Sustainability, TQM and Value Co-Creation Processes: The Role of Critical Success Factors. Sustainability, 8, 995. https://doi.org/10.3390/su8100995

Augusto, M. G., Lisboa, J. V., \& Yasin, M. M. (2014). Organizational Performance and Innovation in the Context of a Total Quality Management Philosophy: An Empirical Investigation. Total Quality Management \& Business Excellence, 25, 1141-1155. https://doi.org/10.1080/14783363.2014.886372

Awan, M. U., Raouf, A., Ahmad, N., \& Sparks, L. (2009). Total Quality Management in Developing Countries: A Case of Pharmaceutical Wholesale Distribution in Pakistan. International Journal of Pharmaceutical and Healthcare Marketing, 3, 363-380. https://doi.org/10.1108/17506120911006056

Bartley, B., Gomibuchy, S., \& Mann, R. (2007). Best Practices in Achieving a Customer Focused Culture. Benchmarking: An International Journal, 14, 482-496. https://doi.org/10.1108/14635770710761889

Bayazit, O. (2003). Total Quality Management (TQM) Practices in Turkish Manufacturing Organizations. The TQM Magazine, 15, 345-350.

https://doi.org/10.1108/09544780310502435

Beamount, N. B., Sohal, A. S., \& Terziovski, M. (1997). Comparing Quality Management Practices in the Australian Service and Manufacturing Industries. International Journal of Quality \& Reliability Management, 14, 814-833. https://doi.org/10.1108/02656719710181321

Berrouiguet, A. Y. (2013). Barriers to Implementing Total Quality Management in Algerian Manufacturing Organizations. Valahian Journal of Economic Studies, 4, 61-66.

Besterfield, D. H., Michna, C. B., Besterfield, G. H., Sacre, M. B., Urdhwareshe, H., \& Urdhwarshe, R. (2012). Total Quality Management (Revised 3rd ed.). New Delhi: Dorling Kindersley Pvt. Ltd.

Bhat, K. S., \& Rajashekhar, J. (2009). An Empirical Study of Barriers to TQM Implementation in Indian Industries. The TQM Magazine, 21, 261-272. https://doi.org/10.1108/17542730910953031

Black, S. A., \& Porter, L. J. (1996). Identification of Critical Factors of TQM. Decision Sciences, 27, 1-21. https://doi.org/10.1111/j.1540-5915.1996.tb00841.x

Brah, S. A., Wong, J. L., \& Rao, B. M. (2000). TQM and Business Performance in the Service Sector: A Singapore Study. International Journal of Operations \& Production Management, 20, 1293-1312. https://doi.org/10.1108/01443570010348262

Bubshait, A. (2007). Benefits and Difficult in Implementing TQM in the Construction Industry. Dhahran: Collage of Environment Design, King Fahd University of Petroleum and Mineral.

Burcher, P. G., Lee, G. L., \& Waddell, D. (2010). “Quality Lives on”: Quality Initiatives and Practices in Australia and Britain. The TQM Journal, 22, 487-498.

https://doi.org/10.1108/17542731011072838

Cătălin, S. H., Bogdan, B., \& Dimitrie, G. R. (2014). The Existing Barriers in Implementing Total Quality Management. Analele Universitatii din Oradea. Stiinte Economice, No. 1, 1234-1240.

Chapman, R., \& Al-Khawaldeh, K. (2002). TQM and Labour Productivity in Jordanian Industrial Companies. The TQM Magazine, 14, 248-262.

https://doi.org/10.1108/09544780210429861 
Charantimath, P. M. (2011). Total Quality Management (2nd ed.). New Delhi: Pearson Education.

Chase, R. B., \& Aquilano, N. J. (1992). Production and Operations Management (6th ed.). Homewood, IL: Irwin.

Chen, R., Lee, Y. D., \& Wang, C. H. (2020). Total Quality Management and Sustainable Competitive Advantage: Serial Mediation of Transformational Leadership and Executive Ability. Total Quality Management \& Business Excellence, 31, 451-468. https://doi.org/10.1080/14783363.2018.1476132

Chin, K. S., \& Pun, K. F. (2002). A Proposed Framework for Implementing Total Quality Management in Chinese Organizations. International Journal of Quality \& Reliability Management, 19, 272-294. https://doi.org/10.1108/02656710210415686

Chin, K. S., Sun, H., Xu, Y., \& Hua, H. (2002). A Comparative Study of Quality Management Practices in Hong Kong and Shanghai Manufacturing Industries. International Journal of Management, 19, 576-581.

Choi, T. Y., \& Eboch, K. (1998). The TQM Paradox: Relations among TQM Practices, Plant Performance, and Customer Satisfaction. Journal of Operations Management, 17, 59-75.

Chong, V. K., \& Rundus, M. J. (2004). Total Quality Management, Market Competition and Organizational Performance. The British Accounting Review, 36, 155-172. https://doi.org/10.1016/j.bar.2003.10.006

Chowdhury, M., Paul, H., \& Das, A. (2007). The Impact of Top Management Commitment of Total Quality Management Practice: An Exploratory Study in the Thai Garment Industry. Global Journal of Flexible Systems Management, 8, 17-29.

https://doi.org/10.1007/BF03396517

Claver, E., Tari, J. J., \& Molina, J. F. (2003). Critical Factors and Results of Quality Management: An Empirical Study. Total Quality Management and Business Excellence, 14, 91-118. https://doi.org/10.1080/14783360309709

Dahlgaard, J. J., Kristensen, K., \& Kanji, G. K. (2007). Fundamentals of Total Quality Management. Abingdon-on-Thames: Taylor and Francis Group.

Dale, B. G. (2003), Managing Quality (4th ed.). Hoboken, NJ: Blackwell Publishing.

Dale, B. G., \& Cooper, C. L. (1994). Introducing TQM: The Role Senior Management. Management Decision, 32, 20-26. https://doi.org/10.1108/00251749410050660

Dale, B. G., Wiele, T. V. D., \& Iwaarden, J. V. (2013). Managing Quality (5th ed.). Hoboken, NJ: Blackwell Publishing.

Das, A., Paul, H., \& Swierczek, F. W. (2008). Developing and Validating Total Quality Management (TQM) Constructs in the Context of Thailand's Manufacturing Industry. Benchmarking: An International Journal, 15, 52-72. https://doi.org/10.1108/14635770810854344

Deming, W. E. (1982). Quality, Productivity and Competition Position (p. 17). Cambridge, MA: MIT Press.

Dóci, E., \& Hofmans, J. (2015). Task Complexity and Transformational Leadership: The Mediating Role of Leaders' State Core Self-Evaluations. The Leadership Quarterly, 26, 436-447. https://doi.org/10.1016/j.leaqua.2015.02.008

Douglas, T. J., \& Judge, W. Q. (2001). Total Quality Management Implementation and Competitive Advantage: The Role of Structural Control and Exploration. Academy of Journal, 44, 158-169.

Doulatabadi, M., \& Yusof, S. M. (2015). Ranking Measures for Sustaining Quality Excel- 
lence Practices: An Empirical Investigation. In M. Gen, K. Kim, X. Huang, \& Y. Hiroshi (Eds.), Industrial Engineering, Management Science and Applications. 2015. Lecture Notes in Electrical Engineering (Vol. 349, pp. 1009-1019). Berlin, Heidelberg: Springer. https://doi.org/10.1007/978-3-662-47200-2_105

Dow, D., Samson, D., \& Ford, S. (1999). Exploding the Myth: Do All Quality Management Practices Contribute to Superior Quality Performance. Production and Operations Management, 8, 1-27. https://doi.org/10.1111/j.1937-5956.1999.tb00058.x

Duarte, A. L. C. M., Brito, L. A. L., Serio, L. C., \& Martins, G. S. (2011). Operational Practices and Financial Performance: An Empirical Analysis of Brazilian Manufacturing Companies. Brazilian Administrative Review, 8, 395-411. https://doi.org/10.1590/s1807-76922011000400004

Eslami, Y., Dassiti, M., Lezoche, M., \& Panetto, H. (2019). A Survey on Sustainability in Manufacturing Organisations: Dimensions and Future Insights. International Journal of Production Research, 57, 5194-5214. https://doi.org/10.1080/00207543.2018.1544723

Feng, J., Prajogo, D. I., Tan, K. C., \& Sohal, A. S. (2006). The Impact of TQM Practices on Performance: A Comparative Study between Australian and Singaporean Organizations. European Journal of Innovation Management, 9, 269-278. https://doi.org/10.1108/14601060610678149

Flynn, B. B., Schroeder, R. G., \& Sakakibara, S. (1994). A Framework for Quality Management Research and an Associated Measurement Instrument. Journal of Operations Management, 11, 339-366. https://doi.org/10.1016/S0272-6963(97)90004-8

Fotopoulos, C. B., \& Psomas, E. L. (2009). The Impact of "Soft" and "Hard" TQM Elements on Quality Management Results. International Journal of Quality and Reliability Management, 26, 150-163. https://doi.org/10.1108/02656710910928798

Fuentes, N. M., Montes, F. J. L., \& Fernandez, L. M. M. (2006). Total Quality Management, Strategic Orientation and Organizational Performance: The Case of Spanish Companies. Total Quality Management \& Business Excellence, 17, 303-323. https://doi.org/10.1080/14783360500451358

Gharakhani, D., Rahmati, H., Farrokhi, M. R., \& Farahmandian, A. (2013). Total Quality Management and Organizational Performance. American Journal of Industrial Engineering, 1, 46-50.

Harris, H., Mccaffer, R., \& Eduw-Fotwe, F. (2013). Modern Construction Management. Hoboken, NJ: John Wiley \& Sons.

Hashmi, K. (2020). Introduction and Implementation of TQM. https://www.isixsigma.com/methodology/total-quality-management-tqm/introduction -and-implementation-total-quality-management-tqm/

Hassan, M., \& Kerr, R. M. (2003). The Relationship between Total Quality Management Practices and Organizational Performance in Service Organisations. The TQM Magazine, 15, 286-291. https://doi.org/10.1108/09544780310486191

Hassan, M., Mukhtar, A., Qureshi, S. U., \& Sharif, S. (2012). Impact of TQM Practices on Firm's Performance of Pakistan's Manufacturing Organizations. International Journal of Academic Research in Business and Social Sciences, 2, 232-259.

Huq, Z., \& Stolen, J. D. (1998). Total Quality Management Contrasts in Manufacturing and Service Industries. International Journal of Quality \& Reliability Management, 15, 138-161. https://doi.org/10.1108/02656719810204757

Idris, M. A., \& Zairi, M. (2006). Sustaining TQM: A Synthesis of Literature and Proposed Research Framework. Total Quality Management \& Business Excellence, 17, 1245-1260. https://doi.org/10.1080/14783360600750535 
Isaksson, R. (2006). Total Quality Management for Sustainable Development: Process Bases System Models. Business Process Management Journal, 12, 632-645. https://doi.org/10.1108/14637150610691046

Isaksson, R., \& Garvare, R. (2003). Measuring Sustainable Development Using Process Models. Managerial Auditing Journal, 18, 649-656. https://doi.org/10.1108/02686900310495142

Ismail Salaheldin, S. (2003). The Implementation of TQM Strategy in Egypt: A Field-Force Analysis. The TQM Magazine, 15, 266-274. https://doi.org/10.1108/09544780310486173

Ismail Salaheldin, S. (2009). Critical Success Factors for TQM Implementation and Their Impact on Performance of SMEs. International Journal of Productivity and Performance Management, 58, 215-237. https://doi.org/10.1108/17410400910938832

Jacobsen, J. (2008). Avoiding Mistakes of the Past: Lessons Learned on What Makes or Breaks Quality Initiatives. The Journal for Quality and Participation, 31, 4-9.

Jancikova, A., \& Brychta, K. (2009). TQM and Organizational Culture as Significant Factors in Ensuring Competitive Advantage: A Theoretical Perspective. Economics \& Sociology, 2, 80-95. https://doi.org/10.14254/2071-789X.2009/2-1/8

Jiang, X. (2009). The Relationship between Manufacturing and Service Provision in Operations Management. International Journal of Business Management, 4, 183-189. https://doi.org/10.5539/ijbm.v4n3p183

Johnson, E. K. (2013). The Practice of Human Resource Management in New Zealand: Strategic and Best Practice? Asia Pacific Journal of Human Resources, 38, 69-83. https://doi.org/10.1177/103841110003800206

Joiner, T. A. (2007). Total Quality Management and Performance: The Role of Organization Support and Co-Worker Support. International Journal of Quality \& Reliability Management, 24, 617-627. https://doi.org/10.1108/02656710710757808

Jun, M., Cai, S., \& Peterson, R. (2004). Obstacles to TQM Implementation in Mexico's Maquiladora Industry. Total Quality Management \& Business Excellence, 15, 59-72. https://doi.org/10.1080/1478336032000149108

Juran, J. M. (1988). Juran on Planning for Quality. London: Collier Macmillan.

Karuppusami, G., \& Gandhinathan, R. (2006). Pareto Analysis of Critical Success Factors of Total Quality Management: A Literature Review and Analysis. The TQM Magazine, 18, 372-385. https://doi.org/10.1108/09544780610671048

Kaynak, E., \& Rogers, R. E. (2013). Implementation of Total Quality Management. A Comprehensive Training Program. New York, London: Routledge. https://doi.org/10.4324/9781315863689

Khan, M. A. (2011). An Empirical Study of Barriers in Implementing Total Quality Management in Service Organizations in Pakistan. Asian Journal of Business Management Studies, 2, 155-161.

Korankye, A. A. (2013). Total Quality Management (TQM): A Source of Competitive Advantage. A Comparative Study of Manufacturing and Service Firms in Ghana. International Journal of Asian Social Science, 3, 1293-1305.

Kristian, F. A., \& Panjaitan, H. (2014). Analysis of Customer Loyalty through Total Quality Service, Customer Relationship Management and Customer Satisfaction. International Journal of Evaluation and Research in Education, 3, 142-151.

Kumar, R., Garg, D., \& Garg, T. K. (2011). TQM Success Factors in North Indian Manufacturing and Service Industries. The TQM Journal, 23, 36-46.

https://doi.org/10.1108/17542731111097470 
Lakhal, L., Passin, F., \& Limam, M. (2006). Quality Management Practices and Their Impact on Performance. International Journal of Quality and Reliability Management, 23, 625-646. https://doi.org/10.1108/02656710610672461

Lee, Y. C. (2004). TQM in Small Manufacturers: An Exploratory Study in China. International Journal of Quality \& Reliability Management, 21, 175-197. https://doi.org/10.1108/02656710410516970

Lee, Y. D., McLee, Y., \& Huang, C. F. (2011). The Status of Leadership Studies: Its Invisible Network of Knowledge. International Journal of Management and Technology, 1, 167-182.

Lin, C., Chow, W. S., Madu, C. N., Kuei, C. H., \& Yu, P. P. (2005). A Structural Equation Model of Supply Chain Quality Management and Organizational Performance. International Journal of Production Economics, 96, 355-365. https://doi.org/10.1016/j.ijpe.2004.05.009

Luburic, R. (2015). Quality Management Principles and Benefits of Their Implementation in Central Banks. Journal of Central Banking Theory and Practice, 4, 91-121. https://doi.org/10.1515/jcbtp-2015-0013

Magd, H. (2015). TQM and Strategic Alliances: Development and Validation in the Context of Egyptian Manufacturing Sector. International Journal of Strategic Business Alliances, 4, 39-64. https://doi.org/10.1504/IJSBA.2015.069309

Magd, H., \& Curry, A. (2003). ISO 9000 and TQM: Are They Complementary or Contradictory to Each Other? The TQM Magazine, 15, 244-256. https://doi.org/10.1108/09544780310486155

Malik, S. A., Iqbal, M. Z., Shaukat, R., \& Yong, J. (2010). TQM Practices and Organizational Performance: Evidence from Pakistan SMEs. International Journal of Engineering \& Technology, 10, 26-31.

Martínez-Costa, M., Choi, T., Martínez, J. A., \& Martínez-Lorente, A. R. (2009). ISO 9000/1994, ISO 9001/2000 and TQM: The Performance Debate Revisited. Journal of Operations Management, 27, 495-511. https://doi.org/10.1016/j.jom.2009.04.002

McAdam, R., \& Bannister, A. (2001). Business Performance Measurement and Change Management within a TQM Framework. International Journal of Operations \& Production Management, 21, 88-108. https://doi.org/10.1108/01443570110358477

Metaxas, I. N., \& Koulouriotis, D. E. (2014). A Theoretical Study of the Relation between TQM, Assessment and Sustainable Business Excellence. Total Quality Management, 25, 494-510. https://doi.org/10.1080/14783363.2013.867608

Milakovich, M. E. (1990). Total Quality Management in the Public Sector. National Productivity Review, 10, 195-215. https://doi.org/10.1002/npr.4040100208

Miller, W. J. (1996). A Working Definition for Total Quality Management (TQM) Researchers. Journal of Quality Management, 1, 149-159. https://doi.org/10.1016/S1084-8568(96)90011-5

Moballeghi, M., \& Moghaddam, G. G. (2011). Linking TQM and Financial Performance. 3rd International Conference on Information and Financial Engineering, Shanghai, 417-422.

Mosadeghrad, A. (2014). Why TQM Programmes Fail? A Pathology Approach. The TQM Journal, 26, 160-187. https://doi.org/10.1108/TQM-12-2010-0041

Motwani, J. (2001). Critical Factors and Performance Measures of TQM. The TQM Magazine, 13, 292-300. https://doi.org/10.1108/13683040010362300

Ngambi, M. T., \& Nkemkiafu, A. G. (2015). The Impact of Total Quality Management on 
Firm's Organizational Performance. American Journal of Management, 15, 69-85.

Nwabueze, U. (2001). An Industry Betrayed: The Case of Total Quality Management in Manufacturing. The TQM Magazine, 13, 400-409. https://doi.org/10.1108/EUM0000000006177

O’Neill, P., Sohal, A., \& Teng, C. W. (2016). Quality Management Approaches and Their Impact on Firms' Financial Performance-An Australian Study. International Journal of Production Economics, 171, 381-393. https://doi.org/10.1016/j.ijpe.2015.07.015

Osuagwu, L. (2002). TQM Strategies in a Developing Economy: Empirical Evidence from Nigerian Companies. Business Process Management Journal, 8, 140-160. https://doi.org/10.1108/14637150210425108

Oza, H., \& Shiroya, D. (2015). Critical Success Factors for TQM in Manufacturing Sectors: A Secondary Data Analysis. International Journal in Management and Social Science, 3, 214-229.

Pambreni, Y., Khatibi, A., Azam, S. M. F., \& Tham, J. (2019). The Influence of Total Quality Management toward Organization Performance. Management Science Letters, 9, 1397-1406. https://doi.org/10.5267/j.msl.2019.5.011

Peris-Ortiz, M., Álvarez-García, J., \& Rueda-Armengot, C. (2015). Achieving Competitive Advantage through Quality Management. Cham: Springer.

https://doi.org/10.1007/978-3-319-17251-4

Pino, R. M. (2008). TQM Practices in Manufacturing and Service Companies in Peru. Journal of Centrum Cathedra, 1, 47-56.

Polat, G., Damci, A., \& Tatar, Y. (2011). Barriers and Benefits of Total Quality Management in the Construction Industry: Evidence from Turkish Contractors. Proceedings of Seventh Research/Expert Conference with International Participation, Neum, Bosnia and Herzegovina, 1-4 June 2011, 1115-1120.

Powell, T. C. (1995). Total Quality Management as Competitive Advantage: A Review and Empirical Study. Strategic Management Journal, 16, 15-37. https://doi.org/10.1002/smj.4250160105

Prajogo, D. I. (2005). The Comparative Analysis of TQM Practices and Quality Performance between Manufacturing and Service Firms. International Journal of Service Industry Management, 16, 217-228. https://doi.org/10.1108/09564230510601378

Prajogo, D. I., \& Brown, A. (2006). Approaches to Adopting Quality in SMEs and the Impact on Quality Management Practices and Performance. Total Quality Management, 17, 555-566. https://doi.org/10.1080/14783360600588042

Prajogo, D. I., \& Sohal, A. S. (2003). The Relationship between TQM Practices, Quality Performance, and Innovation Performance: An Empirical Examination. International Journal of Quality \& Reliability Management, 20, 901-918. https://doi.org/10.1108/02656710310493625

Psychogios, A. G., \& Priporas, C. V. (2007). Understanding Total Quality Management in Context: Qualitative Research on Managers' Awareness of TQM Aspects in the Greek Service Industry. The Qualitative Report, 12, 40-66.

Quek, E. E., \& Yusof, S. M. (2003). A Survey of TQM Practices in the Malaysian Electrical and Electronic Industry. Total Quality Management, 14, 63-77. https://doi.org/10.1080/14783360309708

Rad, A. M. (2006). The Impact of Organizational Culture on the Successful Implementation of Total Quality Management. The TQM Magazine, 18, 606-625.

https://doi.org/10.1108/09544780610707101 
Rad, A. M. M. (2005). A Survey of Total Quality Management in Iran: Barriers to Successful Implementation in Health Care Organizations. International Journal of Health Care Quality Assurance, 18, 12-44. https://doi.org/10.1108/13660750510611189

Rahman, S. (2001). A Comparative Study of TQM Practice and Organizational Performance of SMEs with and without ISO 9000 Certification. International Journal of Quality \& Reliability Management, 18, 35-49.

https://doi.org/10.1108/02656710110364486

Rahman, S. U., \& Bullock, P. (2005). Soft TQM, Hard TQM, and Organizational Performance Relationships: An Empirical Investigation. The International Journal of Management Science, 33, 73-83. https://doi.org/10.1016/j.omega.2004.03.008

Rahman, Z., \& Siddiqui, J. (2006). Exploring Total Quality Management for Information Systems in Indian Firms: Application and Benefits. Process Management Journal, 12, 622-631. https://doi.org/10.1108/14637150610691037

Robson, A., Prabhu, V. B., \& Mitchell, Eds. (2002). TQM Enablers and Business Sustainability: An Empirical Study of the Service Sector in the North East of England. International Journal of Quality \& Reliability Management, 19, 610-632. https://doi.org/10.1108/02656710210427566

Sadikoglu, E., \& Olcay, H. (2014). The Effects of Total Quality Management Practices on Performance and the Reasons of and the Barriers to TQM Practices in Turkey. Advances in Decision Sciences, 2014, Article ID: 537605.

Salegna, G., \& Fazel, F. (2000). Obstacles to Implementing TQM. Quality Progress, 33, 53-64.

Saleh, R. A., Sweis, R. J., \& Saleh, F. I. M. (2018). Investigating the Impact of Hard Total Quality Management Practices on Operational Performance in Manufacturing Organizations: Evidence from Jordan. Benchmarking: An International Journal, 25, 2040-2064. https://doi.org/10.1108/BIJ-05-2016-0074

Samat, N., Ramayah, T., \& Saad, N. M. (2006). TQM Practices, Service Quality, and Market Orientation: Some Empirical Evidence from a Developing Country. Management Research News, 29, 713-728. https://doi.org/10.1108/01409170610716025

Samson, D., \& Terziovski, M. (1999). The Relationship between Total Quality Management Practices and Operational Performance. Journal of Operations Management, 17, 393-409. https://doi.org/10.1016/S0272-6963(98)00046-1

Sebastianelli, R., \& Tamimi, N. (2003) Understanding the Obstacles to TQM Success. Quality Management Journal, 10, 45-56. https://doi.org/10.1080/10686967.2003.11919072

Seetharaman, A., Sreenivasan, J., \& Boon, L. P. (2006). Critical Success Factors of Total Quality Management. Quality \& Quantity, 40, 675-695. https://doi.org/10.1007/s11135-005-1097-2

Shaari, J. A. N. (2010). Barriers to Implement TQM in Japanese Way: A Study on Companies in Malaysia. International Review of Business Research Papers, 6, 400-410.

Shafiq, M., Lasrado, F., \& Hafeez, K. (2019). The Effect of TQM on Organizational Performance: Empirical Evidence from the Textile Sector of a Developing Country Using SEM. Total Quality Management and Business Excellence, 30, 31-52. https://doi.org/10.1080/14783363.2017.1283211

Shouman, B., \& Othman, A. (2014). Total Quality Management as a Strategic Option for Achieving Competitive Advantage in Architectural Design Firms: A Literature Review. International Conference on Industry Academia Collaboration, 3-5 March 2014, Cairo, $1-7$. 
Shrivastava, R. L., Mohanty, R. P., \& Lakhes, R. R. (2006). Linkages between Total Quality Management and Organizational Performance: An Empirical Study for Indian Industry. Production Planning \& Control, 17, 13-30. https://doi.org/10.1080/09537280500324265

Sila, I. (2007). Examining the Effects of Contextual Factors on TQM and Performance through the Lens of Organizational Theory: An Empirical Study. Journal of Operations Management, 25, 83-109. https://doi.org/10.1016/j.jom.2006.02.003

Singh, V., Kumar, A., \& Singh, T. (2018). Impact of TQM on Organizational Performance: The Case of Indian Manufacturing and Service Industry. Operations Research Perspective, 5, 199-217. https://doi.org/10.1016/j.orp.2018.07.004

Sureshchandar, G. S., Chandrasekharan, R., Anantharaman, R. N., \& Kamalanabhan, T. J. (2002). Management's Perception of Total Quality Service in the Banking Sector of Developing Economy-A Critical Analysis. International Journal of Bank Marketing, 20, 181-196. https://doi.org/10.1108/02652320210432963

Sweis, R. J., Saleh, R. A., Al-Ettayem, R. H., Qasrawi, B. T., \& Mahmoud, A. M. (2016). Total Quality Management Practices and Organisational Performance in Jordanian Courier Services. International Journal of Productivity and Quality Management, 19, 258-276. https://doi.org/10.1504/IJPQM.2016.078889

Talha, M. (2004). Total Quality Management (TQM): An Overview. The Bottom Line, 17, 15-19. https://doi.org/10.1108/08880450410519656

Talib, F., \& Rahman, Z. (2012). Total Quality Management Practices in Manufacturing and Service Industries: A Comparative Study. International Journal of Advanced Operations Management, 4, 155-176. https://doi.org/10.1504/IJAOM.2012.047634

Talib, F., Rahman, Z., \& Qureshi, M. N. (2011). Analysis of Interaction among the Barriers to Total Quality Management Implementation Using Interpretive Structural Modeling Approach. Benchmarking: An International Journal, 18, 563-587. https://doi.org/10.1108/14635771111147641

Tan, B. (2013). TQM Adoption and Organizational Performance of Family Owned Businesses: A Literature Review and Proposed Structural Model. International Journal of Modelling in Operations Management, 3, 1-19. https://doi.org/10.1504/IJMOM.2013.052053

Temtime, Z. T., \& Solomon, G. H. (2002). TQM and the Planning Behaviour of SMEs in Developing Economies. The TQM Magazine, 14, 181-191. https://doi.org/10.1108/09544780210425900

Tena, A. B. (2004). TQM as a Competitive Factor: A Theoretical and Empirical Analysis. International Journal of Quality \& Reliability Management, 21, 612-637. https://doi.org/10.1108/02656710410542034

Terziovski, M., \& Samson, D. (1999). The Link between Total Quality Management Practice and Organization Performance. International Journal of Quality \& Reliability Management, 16, 226-237. https://doi.org/10.1108/02656719910223728

Twaissi, N. M., Rollins, R., \& Worsdale, G. (2008). A Review of Current Issues and Challenges for TQM Implementations in the Jordanian Information and Communications Technology Sector. Middle East Quality Association, e-TQM College.

Valmohammadi, C. (2012). Investigating Innovation Management Practices in Iranian Organizations. Innovation: Organization \& Management, 14, 247-255. https://doi.org/10.5172/impp.2012.14.2.247

Wali, A. A., Deshmukh, S. G., \& Gupta, A. D. (2003). Critical Success Factors of TQM: A Select Study of Indian Organizations. Production Planning \& Control, 14, 3-14. 
https://doi.org/10.1080/0953728021000034781

Woon, K. C. (2000). TQM Implementation: Comparing Singapore's Service and Manufacturing Leaders. Managing Service Quality, 10, 318-331.

https://doi.org/10.1108/09604520010345777

Yazdani, A., Soukhakian, M. A. \& Mozaffari, M. R. (2013). Evaluation of Critical Success Factors in Total Quality Management Implementation and Prioritization with AHP-Case Study: Pars Oil and Gas Company. European Online Journal of Natural and Social Sciences, 2, 1624-1633.

Yusof, S. R. M., \& Aspinwall, E. (1999). Critical Success Factors for Total Quality Management Implementation in Small and Medium Enterprises. Total Quality Management, 10, 803-809. https://doi.org/10.1080/0954412997839

Zakuan, N. M., Yusof, S. M., Laosirihongthong, T., \& Shaharoun, A. M. (2010). Proposed Relationship of TQM and Organizational Performance Using Structured Equation Modelling. Total Quality Management, 21, 185-203.

https://doi.org/10.1080/14783360903550020

Zaman, A., \& Anjalin, U. (2016). Implementing TQM in Education: Compatibility and Challenges. Open Journal of Social Sciences, 4, 207-217.

https://doi.org/10.4236/jss.2016.411017

Zhang, Z., Waszink, A., \& Wijngaard, J. (2000). An Instrument for Measuring TQM Implementation for Chinese Manufacturing Companies. International Journal of Quality and Reliability Management, 17, 730-755. https://doi.org/10.1108/02656710010315247 


\section{Appendix}

Table A1. Review from studies on key TQM constructs identified from literature leading to organizational performance in manufacturing and service sectors.

\begin{tabular}{|c|c|c|c|c|c|c|c|c|c|c|c|c|c|c|c|c|}
\hline $\begin{array}{c}\text { Key TQM } \\
\text { practices }\end{array}$ & 1 & 2 & 3 & 4 & 5 & 6 & 7 & 8 & 9 & 10 & 11 & 12 & 13 & 14 & 15 & 16 \\
\hline \multicolumn{17}{|l|}{ Authors } \\
\hline Powell, 1995 & $\mathrm{X}$ & & & & & & & & & & $\mathrm{X}$ & & & & & \\
\hline Choi and Eboch, 1998 & & & & $\mathrm{X}$ & & & $\mathrm{X}$ & $\mathrm{X}$ & $\mathrm{X}$ & & & & & & & \\
\hline Dow et al., 1999 & & & $\mathrm{X}$ & & & & & & & & & $\mathrm{X}$ & & & $\mathrm{X}$ & \\
\hline Rahman and Bullock, 2005 & & & $\mathrm{X}$ & & & $\mathrm{X}$ & & & & $\mathrm{x}$ & & $\mathrm{X}$ & & & $\mathrm{X}$ & \\
\hline Prajogo and Sohal, 2003 & & $\mathrm{X}$ & $\mathrm{X}$ & $\mathrm{X}$ & & & & $\mathrm{X}$ & $\mathrm{X}$ & & & & & & & $\mathrm{X}$ \\
\hline Terziovski and Samson, 1999 & & $\mathrm{X}$ & $\mathrm{X}$ & $\mathrm{X}$ & & & & $\mathrm{X}$ & $\mathrm{X}$ & & & & & & & $\mathrm{X}$ \\
\hline Motwani, 2001 & $\mathrm{X}$ & & $\mathrm{X}$ & & $\mathrm{X}$ & $\mathrm{X}$ & & & & & $\mathrm{X}$ & & $\mathrm{X}$ & $\mathrm{X}$ & & $\mathrm{X}$ \\
\hline Feng et al., 2006 & & $\mathrm{X}$ & $\mathrm{X}$ & $\mathrm{X}$ & & & & & & & & & & & & $\mathrm{X}$ \\
\hline Brah et al., 2000 & $\mathrm{X}$ & & $\mathrm{X}$ & & & & $\mathrm{X}$ & & & & $\mathrm{X}$ & $\mathrm{X}$ & & & & \\
\hline Hassan and Kerr, 2003 & $\mathrm{X}$ & & $\mathrm{X}$ & & $\mathrm{X}$ & $\mathrm{X}$ & $\mathrm{X}$ & & & & & $\mathrm{X}$ & $\mathrm{X}$ & $\mathrm{x}$ & & \\
\hline Samson and Terziovski, 1999 & & $\mathrm{X}$ & $\mathrm{X}$ & $\mathrm{X}$ & & & & & & & & & & & & \\
\hline Shafiq et al., 2019 & & $\mathrm{X}$ & & $\mathrm{x}$ & & & & $\mathrm{X}$ & & & & & & & & $\mathrm{X}$ \\
\hline Malik et al., 2010 & $\mathrm{X}$ & & $\mathrm{x}$ & & & $\mathrm{X}$ & & & & & $\mathrm{X}$ & $\mathrm{X}$ & $\mathrm{X}$ & & & \\
\hline Chong and Rundus, 2004 & & & $\mathrm{X}$ & & $\mathrm{X}$ & & & & & & & & & & & \\
\hline Fotopoulos \& Psomas, 2009 & & $\mathrm{X}$ & $\mathrm{X}$ & & & $\mathrm{X}$ & & $\mathrm{X}$ & $\mathrm{X}$ & $\mathrm{X}$ & & $\mathrm{X}$ & & & & $\mathrm{X}$ \\
\hline Hassan et al., 2012 & & & $\mathrm{X}$ & & & & & & & $\mathrm{X}$ & & $\mathrm{X}$ & & & & $\mathrm{X}$ \\
\hline Rahman, 2001 & & $\mathrm{X}$ & $\mathrm{X}$ & & $\mathrm{X}$ & & & $\mathrm{X}$ & $\mathrm{X}$ & & $\mathrm{X}$ & $\mathrm{X}$ & & & & $\mathrm{X}$ \\
\hline Pambreni et al., 2019 & & & $\mathrm{x}$ & & & & & $\mathrm{X}$ & & $\mathrm{X}$ & & $\mathrm{X}$ & & & & \\
\hline Total occurrences & 5 & 7 & 15 & 6 & 4 & 5 & 3 & 7 & 5 & 4 & 5 & 9 & 3 & 2 & 2 & 8 \\
\hline
\end{tabular}

Dimensions: 1 = top management commitment; 2 = leadership; 3 = customer focus/involvement; 4 = HRM; 5 = product/process design; 6 ; supplier management; 7 = process quality; $8=$ strategic quality planning; $9=$ information $\&$ analysis; $10=$ continuous improvement; $11=$ employee empowerment; $12=$ employee involvement/workforce commitment; 13 = benchmarking; 14 = training; 15 = shared vision; 16 = process management. 